\title{
Med evropeizacijo in nacionalizacijo
}

\author{
Nataša Gliha Komac-Karmen Kenda-Jě̆
}

Cobiss: 1.19

Slovanski jeziki: iz preteklosti v prihodnost, ur. Vojko Gorjanc, Ljubljana: Znanstvena založba Filozofske fakultete, 2012, 151 str.

0 Komisija za slovanske knjižne jezike pri Mednarodnem slavističnem komiteju na svojih srečanjih že vrsto let redno spremlja dinamiko razvoja slovanskih knjižnih jezikov. Znanstvena monografija Slovanski jeziki: iz preteklosti v prihodnost prinaša izbor prispevkov udeležencev ljubljanskega sestanka z začetka junija 2012, posvečenega izzivom spremenjenih jezikovnih situacij v slovanskem svetu. Vsebuje enajst prispevkov uglednih slovanskih jezikoslovcev, ki jih poleg temeljitega tematskega strokovnega vpogleda odlikuje razmislek o povezanosti preteklih, sodobnih in prihodnjih jezikovnopolitičnih razmer v slovanskem prostoru ter zavest o vpetosti razreševanja jezikovnopolitičnih vprašanj v evropsko jezikovno in družbeno stvarnost.

Monografija je sestavljena iz treh delov, ki sistematično odstirajo vpogled v jezikovno stvarnost in prihodnost slovanskih jezikov.

1 V skladu z naslovom je prvi del monografije posvečen diahronim vprašanjem. Robert Grošelj v prispevku Medjezikovna razmerja in vezljivost na gradivu določíl glagolov umevanja opazuje vpliv jezikovnega stika na vezljivost v razvoju štirih južnoslovanskih knjižnih jezikov (stare cerkvene slovanščine, slovenščine, hrvaščine in srbščine). Pri tem je ob razčlembi problematike neposrednega vpliva jezikovnih razmerij, kot so določanje grecizmov, balkanizmov, romanizmov, germanizmov in slavizmov v korpusu in njihova tipologija (vprašanje mehaničnega in sistemskega kalkiranja, sprožitve razvoja inherentnih slovničnih možnosti ob jezikovnem stiku), posebej predstavljeno vprašanje posrednega vpliva - vezljivostnih premikov, povezanih s procesom standardizacije. Zgled za to je nadomestitev določila tipa od + samostalniško določilo v rodilniku s tipom o + samostalniško določilo $v$ mestniku v knjižni slovenščini in hrvaščini 19. stoletja.

2 Razprave drugega dela zbornika se ukvarjajo s sodobnimi izzivi spremenjene družbene in jezikovne stvarnosti izbranih slovanskih jezikov v zadnjih dveh desetletjih, pri čemer je posebej poudarjena vloga jezikovnega načrtovanja kot izhodišča za jezikovno politiko. V predgovoru omenjena zamisel o postopnem načrtnem 
predstavljanju jezikovnih razmer kot eni izmed nalog Komisije za slovanske knjižne jezike je tu uresničena $\mathrm{z}$ dvema sklopoma prispevkov, ki se podrobneje ukvarjajo z jezikovno situacijo v Bolgariji oz. Sloveniji.

Prvi trije prispevki tako $\mathrm{z}$ različnih vidikov ocenjujejo spremembe bolgarskega jezika in njegovega položaja po političnih spremembah v devetdesetih letih 20. stoletja. Diana Ivanova se v razpravi Sodobna bolgarska jezikovna situacija: jezikovne težnje in spremembe v jeziku $v$ devetdesetih letih 20. stoletja ukvarja z drugačno vlogo knjižnega jezika, z novim jezikovnim okusom, napetostmi med procesi liberalizacije in normativizacije, intelektualizacije in kolokvializacije, javnim in zasebnim jezikom ter vplivom množičnih občil. Izsledki so ponazorjeni z leksičnim gradivom. Obravnava je nastala ob upoštevanju sočasnih razvojnih teženj v slovanskih jezikih, pri čemer ob pri nas še vedno prevladujoči dvopolnosti knjižno - neknjižno velja opozoriti na njeno mnenje (str. 34), da so procesi demokratizacije v jezikoslovje slovanskih jezikov prinesli tudi pojmovanje »splošnega nacionalnega « jezika kot »organske celote«, v kateri podsistemi vzajemno delujejo drug na drugega in se zlivajo med seboj. Kina Vačkova (Bolgarski jezikovni zakoni in zakonodaja na področju izobraževanja) predstavlja status bolgarskega jezika v zakonih, ki se nanašajo na izobraževanje od predšolske do visokošolske stopnje. Zlasti zanimiva je izrecno poudarjena vloga knjižnega jezika in upoštevanja knjižnojezikovnih norm v vseh govornih položajih v predpisih za osnovne in srednje šole, kar je že jezikovnopolitični odziv na potekajoče spremembe. Predstavitev bolgarske jezikovne stvarnosti končuje razprava Nadke Nikolove, ki v prispevku Purizem - preživelo ali večno načelo bolgarske družbe popisuje zgodovino purizma v bolgarščini. Ta se je v obdobju vzpostavljanja knjižnojezikovne norme oblikoval predvsem kot zahteva po odpravljanju turcizmov, grecizmov in rusizmov, po prvi svetovni vojni pa je v družbi prevladala naklonjenost do sprejemanja tujega besedja kot sredstva za kulturno internacionalizacijo in evropeizacijo. Današnje razmere kljub posamičnim zahtevam po zakonu o »čistosti« bolgarskega jezika ocenjuje kot liberalne, kar v prilogi dokumentira z odlomki iz jezikoslovnih in laičnih besedil na to temo.

Med oba sklopa sta umeščena prispevka, posvečena jezikovni problematiki manjšin. V prvem (Sodobni razvoj zgornjelužiškega knjižnega jezika - težnje in problemi) Jana Šołćina prikazuje razvojne težnje v zgornji lužiščini (upad števila govorcev, izgubljanje medgeneracijskega posredovanja jezika, večja zmožnost mladih v nemščini in upadanje ravni znanja zgornje lužiščine zaradi izobraževanja $\mathrm{v}$ jezikovno heterogenem okolju), nato pa obravnava pomen jezikovnokulturne dejavnosti za ohranjanje knjižne norme v razmerah neuravnotežene zgornjelužiško-nemške dvojezičnosti. Pri tem poudarja, da so predmet jezikovne kulture tudi kodno preklapljanje, mešanje kodov in pojavi interference. Ena izmed možnih strategij ohranjanja jezikovne zmožnosti je prisotnost zgornje lužiščine v sodobnih medijih. Kot zgled sodobnega jezikovnega svetovanja avtorica predstavlja v lužiščini sicer tradicionalno uveljavljeni model jezikovnih kotičkov, ki jih za radio (in internetni arhiv) od leta 2004 pripravljajo sodelavke jezikoslovne sekcije Lužiškosrbskega inštituta. Juraj Glovňa (Vojvodinska slovaščina v procesu evropske integracije) se ukvarja s slovaščino v Vojvodini, ki se že 270 let razvija v manjšinski skupnosti. Obravnava je osredotočena na poimenovalne razlike med osrednjeslovaškim 
knjižnim jezikom in njegovo vojvodinsko različico, na tematiko, ki bi se je bilo treba lotiti tudi v slovenskem prostoru. Pomembna je njegova ugotovitev, da razlike $\mathrm{v}$ administrativnem izrazju, povezanem z evropskimi integracijskimi procesi, kakršne obstajajo v osrednji slovaščini in slovaščini vojvodinskih Slovakov, ki je izrazje prevzemala s srbskim posredovanjem, lahko vplivajo tudi na ohranjanje narodne in jezikovne identitete skupnosti.

V ruščini objavljeni prispevek Vojka Gorjanca Izzivi sodobnosti in jezikovno načrtovanje $v$ Sloveniji začenja slovenski sklop v monografiji. V njem avtor na kratko predstavlja zgodovino slovenskega jezikovnega načrtovanja po drugi svetovni vojni, poudarja pomen gibanja Slovenščina v javnosti za polnofunkcijski razvoj slovenščine $\mathrm{v}$ sedemdesetih in osemdesetih letih prejšnjega stoletja (kljub njeni omejeni rabi na določenih področjih javne komunikacije), potem pa se osredotoči na vprašanje sedanjega jezikovnega načrtovanja, kakor se odraža v poosamosvojitvenem iskanju novih oblik institucionaliziranega delovanja jezikovne politike. Ocena že večkrat opisane dvojnosti slovenskih jezikovnopolitičnih prizadevanj - nasprotja med zaščitniško držo in odprtostjo -, ki se kaže tudi v obeh ideološko različno utemeljenih operativnih jezikovnopolitičnih dokumentih, Resoluciji o nacionalnem programu za jezikovno politiko 2007-2011 in osnutku Nacionalnega programa za jezikovno politiko 2012-2016, je tu opravljena z vidika medjezikovnih in medkulturnih odnosov v prizadevanju za večjezikovnost kot okvir razvoja jezika in jezikoslovja; pri tem avtor posebej opozarja na nerešena jezikovnopolitična vprašanja, ki so povezana z današnjo jezikovno raznolikostjo slovenske družbe.

Pregledno razpravo dopolnjujeta prispevka, ki se ukvarjata z vprašanjem polnofunkcijskega razvoja slovenskega knjižnega jezika. Monika Kalin Golob (Jezik slovenskega visokega šolstva: med zakonodajo, strategijo in vizijo) piše o opredelitvi položaja slovenskega jezika v visokem šolstvu ob vse večji (nenadzorovani) rabi angleščine v izobraževalnem procesu. Okvir za predstavitev slovenskih razmer so tudi negativne izkušnje iz drugih evropskih držav - Nizozemske, Danske, Švedske in Nemčije -, na podlagi katerih je že mogoče predvideti posledice tovrstne internacionalizacije, kot so izguba jezikovnega področja in nezmožnost strokovnega delovanja $\mathrm{v}$ lastnem jeziku. Kot soavtorica predstavlja tisti del osnutka Nacionalnega programa za jezikovno politiko 2012-2016, v katerem so bila $\mathrm{v}$ dogovoru $\mathrm{z}$ nosilci visokošolske in znanstvene politike opredeljena jezikovnopolitična izhodišča za nadaljnjo obravnavo teh vprašanj - prizadevanje za ohranitev statusa slovenščine v visokem šolstvu, razvijanje sporazumevalne zmožnosti v strokovnem jeziku in izboljšanje položaja slovenščine kot jezika znanosti ob smiselnem ponujanju možnosti razvijanja znanja tujih jezikov. Andreja Žele (Slovenščina v pravu) predstavlja slovenščino v pravu kot vzorčni primer razvoja strokovnega jezika v evropskem prostoru od prevodnega jezika Evropske unije do možnosti za preobrazbo v uradno-delovni jezik. Jezikovne značilnosti sodobne pravne slovenščine ocenjuje glede na stopnjo in način terminologizacije, besednovrstno ustreznost, skladenjskopomensko izkoriščenost in primernost besedilotvornih vzorcev, dotika pa se tudi problematike prevajanja kot terminotvornega postopka in nujnosti oblikovanja »vzporednega študijskega predmeta za sprotno jezikovno in jezikoslovno ažuriranje pravne slovenščine«. 
- 3 Zbornik v tretjem delu sklepata dve v prihodnost usmerjeni razpravi. Marina

[N Katnić-Bakaršić v prispevku Diskurzi moči in moč diskurza: $k$ novim premišljanjem

N o jezikovni politiki iz izhodišč kritične analize diskurza obravnava jezikovno politi-

- $\quad$ ko kot enega izmed diskurzov moči ob dejstvu, da v sodobnem svetu jezik vse bolj

त postaja cilj sprememb in nadzora. Razčlemba razmerij med novimi standardnimi

○ jeziki v Bosni in Hercegovini, ki se vzpostavljajo predvsem kot zaščita jezika pred

is Drugim, privede do premisleka o nadaljnjem jezikovnem načrtovanju in predlogov

- za nova izhodišča jezikovne politike v slovanskih državah, ki naj bi izhajala iz odprtosti za Drugega, interkulturnosti, poudarjala razvoj kritične zavesti o jeziku skupaj z zavestjo o ideološkem ozadju, vzpostavila odnos do prevlade angleščine in globalizacije diskurzov ter zasnovala projekte za izboljšanje delovanja družbe, vključevanje manjšin ter učenje jezika sosedov in drugih slovanskih jezikov. Stanisław Gajda (Slovanski jeziki 2050) razmišlja o prihodnosti slovanskih jezikov v Evropi prihodnosti. Ob upoštevanju trenutnih razvojnih teženj, ki se kažejo kot razpetost med integracijo in diferenciacijo oz. - bolj določno - med evropeizacijo in nacionalizacijo, predpostavlja tri možne modele razvoja slovanskih jezikov (prvi temelji na poglabljanju etnično-narodne ideologije, drugi je usmerjen $v$ globalizacijsko poenotenje, tretji pa vzpostavlja ravnotežje med prvima dvema). Prihodnost slovanskih jezikov je tako videna $v$ razmerah »premišljene večjezičnosti« na ravnotežni točki med globalnim in nacionalnim ob odprtosti za večkulturnost.

4 Razprave, zbrane v monografiji Slovanski jeziki: iz preteklosti v prihodnost, tako odstirajo vpogled $\mathrm{v}$ jezikovno stvarnost in izzive izbranih območij slovanskega sveta na prelomu tisočletja. Zaradi osredotočenosti na problematiko južnoslovanskih jezikov lahko knjigo predstavimo tudi kot nekakšno nadaljevanje monografije Med politiko in stvarnostjo: jezikovna situacija v novonastalih državah bivše Jugoslavije (2009), ki je prvič po razpadu nekdanje Jugoslavije v slovenski jezikoslovni prostor prinesla sociolingvistični opis jezikovne situacije na tem področju. Novi zbornik razprav širi perspektivo: s poglobljenim premislekom o aktualnih jezikovnopolitičnih vprašanjih širšega slovanskega prostora lahko pomembno prispeva k jezikovnemu načrtovanju, ki bo usmerjalo »življenje« slovanskih jezikov v skupnem evropskem prostoru. 